\title{
Election Management Systems and Peaceful Alternation of Power between Incumbent and Opposition Governments in Ghana and Nigeria
}

\author{
Harrison Adewale Idowu, N. Oluwafemi 'Femi' Mimiko
}

DOI: https://doi.org/10.22151/politikon.44.5

Harrison Idown is a lecturer at Adekunle Ajasin University, Nigeria and a researcher at the Department of Political Science, Obafemi Awolowo University, Ile-Ife, Nigeria. His research interests include democratization and democracy, electoral politics and comparative studies. Harrison has written articles published in both local and international outlets, including book chapter contributions. One of his recent publications is the co-authored article "Liberia: Understanding Alternative Dispute Resolution Mechanisms in Post-Conflict Societies." Conflict Studies Quarterly 2019 (26): 3-21. He has been privileged to win several fully funded grants to attend local and international conferences. Harrison also serves as a reviewer for several reputable journals. E-mail: idownadewale88@,yahoo.com; bidown@pg-student.oanife.edu.ng.

N. Oluwafemi Femi' Mimiko is a Professor of Political Science at Obafemi Awolowo University (OAU), Ile-Ife, Nigeria. He was SSRC-MacArthur Foundation Visiting Scholar, Watson Institute, Brown University, Providence, RI; Korean Foundation Visiting Fellow, The Academy of Korean Studies, Seoul; and Senior Fulbright Scholar and Visiting Professor, United States Military Academy (USMA), WestPoint, NY. He is a recipient of USMA Army Commander's Public Service Award, 2004; and author of Globalization: The Politics of Global Economic Relations and International Business. Mimiko was Vice Chancellor (President), Adekunle Ajasin University, Nigeria, 2010 to 2015; and member, the National Institute, Kuru, Nigeria. In 2016/2017, he had a stint as African and African-American Studies Associate at Harvard University, Cambridge, MA, USA. His research interests include international relations, comparative political economy, and development and transition studies.E-mail:nomimiko@,oauife.edu.ng; femi.mimiko@gmail.com.

\begin{abstract}
Across most democracies in Africa, election management is largely problematic, and peaceful alternation of power between incumbent and opposition governments is usually infrequent and rancorous. The role of election management systems in such power alternations, specifically in Ghana and Nigeria, is not adequately covered in literature. Adopting an exploratory research design and qualitative methodology, this article explores the role of election management in the peaceful alternation of power between incumbent governments and opposition parties in the countries. It relies on primary data sourced from semi-structured interviews and secondary literature. The results show that, in Ghana, election management system is largely credible, thus, influenced incumbents' willingness to peacefully hand over power to opposition, whereas, in Nigeria, peaceful alternation took place despite flawed election management system. The study concludes that while election management was significant for peaceful power alternation in Ghana, it was not for Nigeria.
\end{abstract}

\section{Keywords}

Alternation of Power; Election Management; Election Management System; Ghana; Government; Incumbent; Nigeria; Opposition 


\section{Introduction}

The article compares the role of election management systems in the peaceful alternation of power in Ghana and Nigeria. The political landscape in Africa witnessed significant change during the 1990s when an unprecedented wave of democratization swept across the continent (Omotola 2010, 1-19). Although multi-party politics with periodic elections seem to have been widely embraced, however, elections for many leaders remain mere veneers to hold on to power. It is for this reason that many scholars are of the view that though democracy has emerged in Africa, it is still not being practiced in the true sense of the word (Marc et al. 2015; Omotola 2011; Sanusi and Nassuna 2017).

Furthermore, despite the claim to democratic practice, alternation of power between incumbent and opposition governments is few and far between on the continent. In many of the instances where such alternations took place, they were neither peaceful nor voluntary - rather, they were 'forced' (Idowu 2018). Such were the cases in Burkina Faso, Cote d'Ivoire and the Gambia. The excuse given by leaders in these countries for their attempts to deny peaceful alternation of power is often related to the manner in which the elections were managed (BBC News 2016; Independent Electoral Commission of Gambia 2016; The Guardian 2016). In many instances, however, leaders manipulate the electoral process in their own favor so as to remain in power like Denis Sassou Nguesso of Republic of Congo and Yoweri Museveni of Uganda.

Existing literature posits that peaceful alternation of power occurs as a consequence of credible elections, to the extent that winners and losers can accept electoral processes and results as binding if elections are credibly managed. The relationship between these two variables has, however, not been established specifically for Ghana and Nigeria. The critical question is to what extent election management influences the transfer of power from incumbents to opposition.

Ghana and Nigeria share certain specificities. In the West African sub-region, Ghana and Nigeria were the first set of countries to gain independence (1957 and 1960 respectively), they are both in their Fourth Republics and they both experienced their first military coups in 1966. They have endured the highest number of incidents of democratic disruptions in the form of military intervention, five in Ghana (same with Sierra Leone and Niger), and six in Nigeria (same with Benin) (Souaré 2010). Both have experienced alternation of power between incumbent and opposition governments, but, while Ghana made significant progress in its electoral process over the years (Idowu 2018) with three alternations from incumbent parties/presidents to opposition parties, Nigeria's electoral process is still largely fraught with irregularities and has had one such transition in 2015. These circumstances justify the choice of the countries for this study. 
This article is structured as follows: after this introduction and the literature review, it will present its theoretical framework and the conceptualization of the terms employed. The following sections will present and analyze the data and discuss the findings. This will be followed by the conclusion and implications for future research.

\section{Literature Review}

The role of election management and election management bodies (EMBs) in democratic transfer of power has been detailed in the literature. Lopez-Pintor (2000) examined EMBs as permanent public institutions of governance in a democratizing world and their role in ensuring credible elections and transfer of power in a study adopting a combination of thematic and country-specific analytical methods. Its major findings are that prospects for a free, fair and credible election lay in the hands of electoral bodies that are independent of the executive and have permanent professional staff, that elections run by independent electoral bodies are preferable to those run by the executives and that elections administered with permanent staff are more cost effective than those substantially run with temporary staff. The study also posits that intervention by the international community has generally been effective in helping both the democratization/transition process, and the establishment of EMBs. There are also a number of guiding principles like independence, impartiality, integrity, transparency, efficiency, professionalism and service-mindedness (Ace Project 2018) that are crucial to the work of electoral authorities.

Dunne and Smith (2012) examined the role of electoral management in transition from authoritarian regimes to democracies. Their study finds that elections are milestones occupying a special place in democratic transition. Accordingly, "the electoral management body (EMB) that supervises, administers and manages free and fair elections fosters trust in the electoral process and improves the prospects of democratic consolidation" (Dunne and Smith 2012, 5). It further establishes that most countries which have experienced transition from authoritarian rule to multiparty democracy have chosen multiparty based EMBs during their transition.

Jinadu's (2014) comparative study examined the role of electoral commissions (ECs) in strengthening democracies in West Africa. With Benin, Cape Verde, Ghana, Nigeria, Senegal and Sierra Leone as case studies, the study adopts interviews, focus group discussions and comparative method to identify and explain similarities and differences among the structures and operations of EMBs in the six countries. It establishes that EMBs with varying histories, political cultures and operating within varying political economies act as independent and intervening variables and points out key historical and material forces that helped frame and shape the electoral management processes in the six countries. These include the state as a site for zero-sum politics, progressive 
violation of the principle of isolation of administration from politics and combination of political and legal influences that help foster a culture of impunity (Jinadu 2014). Among the challenges that face EMBs in the West African sub region are the increasing cost of elections, controversy over electoral dispute adjudication and institutionalizing partnership with stakeholders (Jinadu 2014, 6-16). All these equate to contradictions between the political economy and mainstream ethical values not just in the six countries, but across the African continent.

Oliva (2011) explored the conditions that could determine how actors at elections may handle electoral outcomes - that is, whether such a process engenders alternation of power or not. He argues that elections cannot be perfect and that the acceptance of results by all major political parties is crucial for legitimizing the whole electoral process. Acceptance of election results by the losing party/ies is predicated upon certain conditions. Adopting document analysis approach, the study finds that one of such conditions may include the extension of a hand of fellowship to losers on the part of winners. Doing otherwise could provoke losers to react negatively, which may result in stalemate in the power alternation process and in the post-election political crises which have often marred electoral processes. According to Nadean and Blais $(1993,553)$, what the foregoing suggests is that while winners' enthusiasm towards the political system is predictable, losers' endorsement is "less obvious", especially in cases of profound, close and hard-fought contests.

While the context and variables of these studies vary, one overarching conclusion is that a direct relationship exists between transparency and credibility of elections and the tendency of losers to concede defeat and facilitate peaceful transfer of power. This article will test the validity of this theoretical proposition for Ghana and Nigeria, two countries with broadly similar histories and political trajectories.

\section{Theoretical Framework}

In order to fully capture and analyze the role of election management in peaceful alternation of power between incumbent and opposition in Ghana and Nigeria, the article adopts the rule application (election management) model of electoral governance theory. The theory, as conceptualized by Mozaffar and Schedler $(2002,7)$ consists of "the wider set of activities that creates and maintains the broad institutional framework in which voting and electoral competition take place." According to the proponents, electoral governance is a comprehensive and multitasked activity, involving the three levels of rule-making, rule application and rule adjudication. While rule-making involves designing the basic rules of the electoral game, rule application deals with implementing these rules to organize the electoral game, and rule adjudication entails resolving disputes arising from the contest. 
Winners and losers can accept electoral processes and results as binding provided elections are effectively managed. Effective management is only possible if the EMB has autonomy in terms of its structure, composition, funding and capacity (Catt et al. 2014). This also explains why one of the hallmarks of a mature democracy is professional, independent and non-partisan election administration. In addition, Omotola $(2010,1-19)$ asserts that other relevant institutions, like political parties, mass media, security agencies and civil society organizations (CSOs), are also required to play their own roles effectively, including the provision of logistical support which is vital to the operation of the electoral body. The oversight functions of the legislature and judiciary are also crucial.

The article also adopts the law application (election management) model of electoral governance theory in exploring the nexus between election management and peaceful alternation of power between incumbent and opposition governments in Ghana and Nigeria. The theory suggests that the fairness of election management often determines how winners and losers will react to the outcome. This theory is explored to show the link, if any, between election management and political power alternation in Ghana and Nigeria.

\section{Conceptualization of Election Management System and Alternation of Power}

Election management system refers to the plans/processes put in place to ensure that election management is conducted seamlessly. It is a system that enables an election management body to provide services (election management) at the time they are needed (Idowu 2018), in order for the process, the procedure and outcome of the elections to be acceptable. An election management system contributes to transparent and credible electoral processes when it gives room for free and fair elections and credible voters' register, does not ensure incumbent recycling, does not provoke electoral/democratic frustration through violence, discourages voter inducement and ensures that the electoral process is free from intimidation, repression and fraud.

Political alternation of power occurs when there is a transfer of power from an incumbent to an opposition government who emerged victorious in a transition election. In an electoral democracy, political power alternation is only guaranteed via elections (Idowu and Mimiko 2020). For Cho and Logan $(2013$, 6), political power alternation occurs when incumbent governments and parties lose a transition election and demonstrate that they accept the will of the people by conceding defeat and handing over power to the opposition who won the election. Mbaeze, Okoli and Okonkwo $(2017,19)$ referred to political power alternation as a

"situation where the opposition political party takes over power from the incumbent via a democratic election. Hence, where the incumbent party [or leader] loses an election to the 
opposition party [or candidate] and hands over power to the opposition, then the country has experienced alternation in power."

Idowu and Mimiko (2020) identified two forms of power alternation. The first takes place between incumbent leader/president and opposition parties, and the other is a transfer of power from incumbent political parties to opposition parties. Furthermore, Little, Tucker and LaGatta (2015) identified democratic and semi-democratic alternation of power: while democratic alternation is spontaneous and done willingly by losing incumbent parties and leaders, semidemocratic power alternation is affected and made possible by citizens' protest and pressure from other stakeholders. For this article, alternation of power refers to a situation whereby the incumbent government loses the election, concedes defeat to the opposition and hands over power to an opposition government.

\section{Methodology}

The article adopted an exploratory research design. It relied on primary and secondary data sourced from Ghana and Nigeria. Primary data was collected through semi-structured interviews. A total of 20 Key Informant Interviewees (KIIs) were purposively selected from top officers of election management bodies (EMBs), heads of election observer groups, key officers of electoral institutes and high-ranking members of key political parties in Ghana and Nigeria. The sample size and sample technique adopted is predicated upon the principle that in a qualitative research of this nature, statistical representativeness is not the aim. Rather, respondents are selected because they are likely to generate useful data (Patton and Cochran 2002, 9). Thus, respondents were selected based on their specialization, expertise, experience and practical involvement in election management/observation and the peaceful alternation that occurred in the countries of study. Interviews in both countries lasted between 18 to 54 minutes. While the personalities who lost and won elections in both countries could not be interviewed directly, efforts were made to speak with some of their closest aides. Secondary data was sourced from relevant literature like textbooks, journal articles, newspapers and magazines, official gazettes and documents, and the Internet. Data collected was subjected to discourse analysis.

\section{Data Presentation and Analysis}

\section{Overview of Election Management Systems in Ghana and Nigeria}

The Electoral Commission of Ghana is responsible for the country's election management. It is charged with the responsibility of organizing elections in Ghana and supported by some major 
stakeholders such as social-political groups. ${ }^{1}$ Interviewees pointed out the role and need for support to the Electoral Commission of Ghana (EC) by other stakeholders: Another respondent averred that election management in Ghana is a collective effort involving state agencies, civil societies, local and international media and international organizations. ${ }^{2}$

In the Ghanaian election management system, civil society groups have been identified to play the significant role of ensuring the electoral process' credibility, thus aiding election management and power alternation in the country (Gyekye-Jandoh 2016, 35-62). Corroborating the literature, for instance, during elections, a civil society group, CODEO, conducts Parallel Vote Tabulation: a scientifically designed technology which CODEO uses to check and cross examine the results released by the EC. ${ }^{3}$ The election management system in Ghana created an atmosphere where elections are very important and are now mostly seen as a national festival; as such, most Ghanaians love elections and follow the process with passion according to one District Electoral Director interviewed. ${ }^{4}$ This democratic and electoral atmosphere has also helped the Ghanaian democratic process as it strengthens the credibility of the process.

The Ghanaian election management system produces transparent and credible elections/electoral processes. An interviewee affirmed, with regards to transparency, that

"The process is so transparent from the electoral cycle. From the registration to the results declaration, throughout the process... So that gives that confidence to people. And that is also one of the reasons why people find it difficult to question election results in Ghana." 5

Nonetheless, because elections cannot be perfect (Oliva 2011, 19-31), the Ghanaian election management system is not an exception when it comes to electoral challenges. Specifically, the literature states that there are evidences of electoral fraud in the elections the Ghana EC has presided over since 1992 (Asante-Kissi 2012; Debrah 2001, 75-85). Also, the ineffectiveness in the recruitment and training of temporary staff, as well as the non-compliance to the dictates of the designed electoral rules by the temporary staff have been identified as some of the factors which continue to contribute to the major problems encountered at the registration and polling centers, a situation which affects the EC's performance in electoral management (Asante-Kissi 2012; Ayee 1997; Debrah 2001; Gyimah-Boadi 1999). Corroborating these findings, some interviewees also gave their opinions on some of the challenges the Ghanaian election management system faces.

\footnotetext{
1 Telephone interview with the Director of Research and Election for Eastern Region of the National Democratic Congress (NDC), Ghana. 14.11.2018.

${ }^{2}$ Telephone interview with the Executive Director, Institute for Democratic Governance (IDEG), Ghana. 15.11.2018.

3 Telephone interview with a Research Officer at Centre for Democratic Development (CDD), Ghana and Coalition of Domestic Election Observation (CODEO), Ghana. 5.11.2018

${ }^{4}$ Telephone interview with the District Electoral Director, Ghana EC, 3 December 2018; Interview with the Deputy Country Director, NDI, Nigeria, 18.12.2018.

5 Telephone interview with the District Electoral Director, Ghana EC, 3.12.2018.
} 
An official of NDC stressed that no election can be 100 percent perfect and so, the Ghanaian elections still experience some hitches. ${ }^{6}$ In spite of that, and although there are always attempts to manipulate the electoral process, including vote buying, Ghana has vigilant electorates who are always ready to protect their mandate. ${ }^{7}$ The 'vigilant electorates' here refer to the ordinary citizens who want to see their votes count and not the 'macho men' (political thugs) which Bob-Milliar $(2014,132)$ avers could undermine the democratization process.

Election management in Nigeria involves some major stakeholders like the Independent National Electoral Commission (INEC), political parties, civil society organizations, the media and the entire populace. ${ }^{8}$ The role of civil society groups and the media in election management has been established in the literature. It is through civic organizations that people participate in politics and development. Civil societies also provide networks of communication among citizens and between citizens and the state (Bratton, 1997). According to a respondent:

"In Nigeria, there is the Nigeria election situation room for example. That is a coalition of civil society that come together to engage INEC on all aspects of the electoral process...

INEC uses the opportunity to give update about what they are doing and the civil society people also use that platform to ask questions, make inputs and give advice."

As Schedler (1998) and Whitehead (2003) posit, in addition to elections, the media are seen as instrumental to political accountability and, accordingly, has been a very important tool to both INEC and political parties during electioneering periods. ${ }^{10}$

On the transparency of the process, one TEI official noted that the electoral process is transparent to the extent that all electoral stakeholders participate in all stages of the electoral process. ${ }^{11}$ Nevertheless, the challenges with the Nigerian election management system identified by most of the interviewees negate the above submission. Since the 1999 election, election management in Nigeria has been fraught with challenges like corruption of INEC officials, vote buying, bribery of Electoral Commissioners, unpreparedness of INEC, late arrival of materials at polling stations on election-day and unending litigations. ${ }^{12}$ Other challenges include problems at the collation center, problem with accreditation and registration of voters, malfunctioning of the

\footnotetext{
${ }^{6}$ Telephone interview with the Director of Research and Election for Eastern Region of the National Democratic Congress (NDC), Ghana. 14.11.2018.

7 Telephone interview with the Executive Director, Institute for Democratic Governance (IDEG), Ghana. 15.11.2018.

${ }^{8}$ Interview with the National Coordinator, TMG, Nigeria, 15.12.2018.

${ }^{9}$ Interview with the Deputy Country Director, NDI, Nigeria, 18.12.2018.

${ }^{10}$ Interview with the National Publicity Secretary, PDP, Nigeria, 15.12.2018.

${ }^{11}$ Interview with the Deputy Director, Administration, TEI, Nigeria, 21.12.2018.

${ }^{12}$ Interview with the Special Adviser on Media and Publicity to President Goodluck Jonathan, Nigeria, 27.12.2018.
} 
electronic card reader devices, uneven distribution of permanent voters' card and underage voting. ${ }^{13}$ The problem of padded/inflated voters register has also been identified. ${ }^{14}$

On the part of INEC, they are faced with challenges such as logistics, management of ad hoc staff, training, ensuring credible voters' register, procurement of materials and resources, political parties and candidates' management and election-day support. ${ }^{15}$ Most of these challenges have also been highlighted in the literature (Transition Monitoring Group 2003; Human Rights Watch 2007; Carter Center 1999; Oyekanmi 2015; Kurfi 2005, 34-36; National Democratic Institute (NDI) Report 2008, 8; INEC 2014). Notwithstanding these numerous challenges with the Nigerian election management system, the Special Adviser on Media and Publicity to President Muhammadu Buhari, is of the opinion that there has been significant improvement with the system, especially with the introduction of the new technology - the Electronic Card Reader. ${ }^{16} \mathrm{He}$ added that the reforms have closed the margin of large extent fraud, especially during accreditation.

\section{Election Management System and Peaceful Alternation of Power in Ghana}

From 1996, Ghana has moved from opaque to transparent balloting and, in order to curb cases of impersonation during voting, the voters' ID card now bears its owner's thumb print and picture. ${ }^{17}$ In line with the recommendation that transfer of power should be anchored on a clear and unambiguous policy and guided by a culture of tolerance, accommodation and respect for fundamental human rights (Huntington 2009, 31-69), Ghana seems to have done its part. Prior to 2012, before the country adopted a Transition Act, alternation had been rancorous and marked by incidences of conflict between the incoming and the outgoing governments. ${ }^{18}$ The shortness of the period between the elections (usually held 7 December) and the transition programme (usually 7 January of the following year) often hampers a proper political power alternation between incumbent president and opposition party. ${ }^{19}$ During transition periods in Ghana, there are always few instances of supporters of defeated candidates trying to take laws into their hands; albeit, these have been isolated cases. ${ }^{20}$

\footnotetext{
13 Ibid.

${ }^{14}$ Interview with the Special Adviser on Media and Publicity to President Muhammadu Buhari, Nigeria, 19.12.2018.

${ }^{15}$ Interview with the Special Adviser to the Chairman, INEC, Nigeria, 20.12.2018.

${ }^{16}$ Interview with the Special Adviser on Media and Publicity to President Muhammadu Buhari, Nigeria, 19.12.2018.

17 Telephone interview with the Director of Research and Election for Eastern Region of the New Patriotic Party (NPP), Ghana, 12.12.2018.

${ }^{18}$ Telephone interview with the Executive Director, Institute for Democratic Governance (IDEG), Ghana. 15.12.2018.

${ }_{19}$ Telephone interview with the Eastern Regional Deputy Electoral Director, Ghana EC, 7.12.2018.

${ }^{20}$ Telephone interview with a Research Officer at Centre for Democratic Development (CDD), Ghana and Coalition of Domestic Election Observation (CODEO), Ghana. 5.11.2018.
} 
According to an NDI official, Ghana has an "office that manages transition, it is already institutionalized... So, it is not a period of rancor." ${ }^{21}$ The transition success which Ghana enjoys today is not a mirage - rather, it has come through series of reforms to a point where the culture of democracy is now been largely instilled in the people. According to another interviewee:

"Ghana has escaped probably a decade of any military challenge. There is strong public pressure. We [Ghana] have a history of a culture of vibrant civil societies, endearing civil societies that will tell coup or soldiers by whatever trick to quit."22

In recent times, Ghana has been referred to as the pride of Africa when it comes to peaceful alternation of power between incumbent and opposition governments, having witnessed three of such alternations in 2001, 2009 and 2017 (Songwe 2015; 2016). According to Kerevel (2009, 3), when election management has perceived credibility, the confidence of citizens and politicians in the election outcome receives a boost and there is increased electoral participation and acceptability of election outcome by both winners and losers, making it easier for incumbents to concede defeat and peacefully hand over government to opposition. Al Musbeh (2011) is also of the view that lack of credibility in election management will usually result in diminished public confidence in election results and vice versa. Interviewees reaffirmed these views with specific reference to Ghana: an IDEG official, for example, averred that what makes a result acceptable to a candidate, whether the incumbent president or an opposition candidate, is the credibility of the process. ${ }^{23}$ On the other hand, when elections lack credibility and result in incumbent's loss, it breeds grounds for people to challenge the process and reject the outcome, hence the need to ensure that elections are well managed. ${ }^{24}$

In all instances when incumbent presidents/parties accepted election results, conceded defeat and handed over power to the opposition in Ghana, it has largely been as a result of a transparent electoral process in which the incumbents had confidence. ${ }^{25}$ The Ghanaian electoral process is so transparent that most times, even before the EC declares results, political parties and other keen observers already have the results from their collations at various polling stations. Given such transparency, incumbents are left with no option than to relinquish power when they lose elections. $^{26}$

\footnotetext{
${ }^{21}$ Interview with the Deputy Country Director, NDI, Nigeria, 18.12.2018.

22 Telephone interview with the Executive Director, Institute for Democratic Governance (IDEG), Ghana. 15.12.2018.

${ }^{23}$ Telephone interview with the Executive Director, Institute for Democratic Governance (IDEG), Ghana. 15.11.2018.

${ }^{24}$ Telephone interview with a Research Officer at Centre for Democratic Development (CDD), Ghana and Coalition of Domestic Election Observation (CODEO), Ghana. 5.11.2018.

25 Telephone interview with the District Electoral Director, Ghana EC, 3.12.2018.

${ }^{26}$ Telephone interview with the District Electoral Director, Ghana EC, 3.12.2018.
} 
Election management system was a major factor that had ensured the peaceful alternation of power between incumbent and opposition governments in the country. The transitions were possible mostly because the election management systems were transparent and produced credible elections, which made rejection of results, especially by the incumbents, difficult. ${ }^{27}$ Specifically shedding light upon the 2008 presidential elections and the subsequent alternation in 2009 between incumbent President John Agyekum Kufuor of the New Patriotic Party (NPP) and the opposition presidential candidate John Dramani of the National Democratic Congress (NDC), an interviewee opined that even though the vote difference for the runoff election was only 40,000, the incumbent accepted the result because the process was transparent. The incumbent, thus, believed and had confidence in the election management system. ${ }^{28}$

Referring to the 2016 elections, an official of CODEO averred that:

"The elections were conducted in such a transparent, peaceful, free and fair manner that both the opposition and incumbent governments had no reason to doubt the integrity of the process... Again, the transparency of the process was such that the National Democratic Congress (NDC) had no option but to concede defeat, as the process was free, fair and result at every stage verifiable." 29

Nothing could have warranted an incumbent sit-tight attempt in Ghana as the electoral processes were transparent and produced free, fair, transparent and credible elections. President Dramani would have had no reason to reject the election results, given that the process was transparent and there were also avenues to address challenges at every stage of the process. ${ }^{30}$ Incumbent presidents who have conceded defeat and handed over power in Ghana could have (attempted to) hold onto power if the elections were not transparent and credible, and if they felt their votes were tampered with. ${ }^{31}$ Beyond interviewees' claims on the election management system, a citizens' survey on trust on the EMB and on the election management system in Ghana shows that a larger percentage of the sampled respondents (28.8\%) 'somewhat trusts the system'; $25.1 \%$ 'trust the system a lot'; $22.9 \%$ 'trust the system just a little'; and $18.2 \%$ 'do not trust the system at all' (Afrobarometer 2016/2018, Ghana).

Some of the interviewees agreed that although the elections leading to alternation of power in Ghana were not perfect (as stated by Oliva 2011, 19-31), they nevertheless played a significant role in those peaceful transitions. With specific reference to the December 2016 presidential elections, an official of NDC, avers that:

\footnotetext{
${ }^{27}$ Telephone interview with the Eastern Regional Deputy Electoral Director, Ghana EC, 7.12.2018.

${ }^{28}$ Telephone interview with the District Electoral Director, Ghana EC, 3.12.2018.

${ }^{29}$ E-mail interview with the National Coordinator, CODEO, Ghana, 24.11.2018.

30 Telephone interview with a National Director of Elections, Ghana EC, 24.11.2018.

31 Telephone interview with the Eastern Regional Deputy Electoral Director, Ghana EC, 7.12.2018.
} 
“The former president [John Dramani] had stated that the elections were not transparent and of course, at a point in time, the Electoral Commission's system at the time was hacked... So, yes, you might have problem with the electoral process, but it still does not dispute the fact that our [Ghanaian] system here is very, very transparent." ${ }^{32}$

As such, a few of the interviewees disagreed that electoral credibility was a significant factor in the alternation of power between incumbent and opposition governments in Ghana. For another respondent, in all three alternations between incumbent and opposition governments so far experienced in the country, democratic culture rather than electoral credibility had been largely responsible. ${ }^{33}$ Also, the Communication Specialist of President Dramani, argued that the President did not hand power over because of clean elections, as there were legal grounds to reject the results. Rather, he accepted them because of his personal conviction that the peace of Ghana was greater than his personal ambition..$^{34}$

\section{Election Management System and Peaceful Alternation of Power in Nigeria}

Right from 1999, there has been significant progress in election management and transitioning in Nigeria. ${ }^{35}$ The introduction of technology for the 2015 elections greatly improved the system and produced a more credible electoral outcome, which in turn birthed a unique transition in contrast to the 2007 election, regarded as the worst in the history of the country. ${ }^{36}$ Such technological innovations included the introduction of the smart card reader, permanent voter card and biometric register of voters. However, even though the election management system recorded improvements over past experiences, the system did not seem to play any significant role in the 2015 alternation in Nigeria. ${ }^{37}$ A citizens' survey on trust on the EMB and election management system in Nigeria shows that a larger percentage of the sampled respondents $(33.6 \%)$ 'do not trust the system at all'; 30.6\% 'trust the system just a little'; $22.3 \%$ 'somewhat trust the system'; and just 12.4\% 'trust the system a lot' (Afrobarometer 2016/2018, Nigeria).

The 2015 peaceful alternation of power is most significant in Nigeria, being the first power transfer from an incumbent president to opposition party in the country. Hate campaign, ethnoreligious conflict, unending communal clashes in several Northern states and parts of the North Central and Boko Haram insurgency were some of the intrigues and the circumstances surrounding

\footnotetext{
32 Telephone interview with the Director of Research and Election for Eastern Region of the National Democratic Congress (NDC), Ghana. 14.11.2018.

33 Telephone interview with the National Director of Research and Elections, NPP, Ghana, 17.11.2018.

34 Telephone interview with the Communication Specialist to President Dramani and member of the Ghanaian Parliament, 18.11.2018.

${ }^{35}$ Interview with the National Publicity Secretary, APC, Nigeria, 20.12.2018.

${ }^{36}$ Ibid.

${ }^{37}$ Interview with the National Publicity Secretary, PDP, Nigeria, 15.12.2018.
} 
the 2015 transition (Adebiyi 2015). There were also predictions that the alternation process would not happen should the incumbent president lose the elections (The Nation 2015; Ameh 2014). They suggested that the country was going to break up (Oladesu 2014; Oyekanmi 2015). The opinions of interviewees on the 2015 election management and transition confirmed the literature. For instance, a respondent recounted that during the 2015 election, there was a lot of tension and people threatened that if their candidates did not win, there would be bloodshed. ${ }^{38}$ By virtue of President Jonathan's concession, however, the tension was minimized and impending crisis was abatedPrior to the 2015 presidential election, incumbent presidents/parties had never lost elections in Nigeria and, as such, there had not been any alternation of power in the country. The tide turned during the 2015 presidential election when incumbent President Goodluck Jonathan contested in the election, lost, conceded defeat and handed over power to the victorious opposition party's (APC) presidential candidate, General Muhammadu Buhari (Idowu 2018). This marked the first transfer of power from an incumbent government to an opposition government in the history of the country. The 2015 elections had improved immensely over the past ones - as such, the incumbent president could not have done otherwise than to allow the alternation process. ${ }^{39}$ President Jonathan was aware that he had lost his support in the country and also knew he had credibly lost the elections -hence, he was left with no option than to relinquish power. ${ }^{40}$

Despite the issues recorded with the 2015 presidential election, it was largely adjudged as credible by local and international observers and, as such, paved the way for the 2015 alternation of power. ${ }^{41}$ Although not everyone thought that the process was perfect, the prevailing opinion seemed to support the thesis that the election was credible. ${ }^{42}$ Many reasons accounted for Jonathan's concession, one being that the electoral process was transparent and appeared credible, especially the new technology that was introduced to prevent electoral fraud. ${ }^{43}$

Pressure from the international community is believed to have also played a huge role in the transition (Idowu 2018). Furthermore, even among those interviewees who felt the 2015 election management system was relatively credible, some felt that the then incumbent People's Democratic Party (PDP) had plans to scuttle the entire alternation process. This implies that, although the election was largely credible, that was not sufficient to convince the incumbent to concede and hand over power seamlessly (Idowu 2018). Hence, some interviewees were of the

\footnotetext{
${ }^{38}$ Interview with the Special Adviser on Media and Publicity to President Goodluck Jonathan, Nigeria, 27.12.2018.

${ }^{39}$ Interview with the Special Adviser on Media and Publicity to President Muhammadu Buhari, Nigeria, 19.12.2018.

40 Ibid.

${ }^{41}$ Interview with the National Coordinator, TMG, Nigeria, 15.12. 2018; Interview with the Deputy Director, Election Monitoring Department, INEC, Nigeria, 18.12.2018.

${ }^{42}$ Interview with the National Publicity Secretary, APC, Nigeria, 20.12.2018.

${ }^{43}$ Interview with a Senior Fellow, CDD, Nigeria, 15.12.2018.
} 
opinion that free and fair elections alone do not guarantee successful governance or a peaceful transition/alternation, and that the disruption of the national result collation exercise during the 2015 election was an attempt to cause confusion and stall the process. ${ }^{44}$

For most of the interviewees, rather than electoral credibility, factors such as the personality of incumbent President Jonathan, efforts of the National Peace Committee (NPC) and pressures from domestic and international community played a significant role in the peaceful alternation of power (Idowu and Mimiko 2020). For instance, speaking as an insider, an interviewee argued that President Jonathan's concession and handing over of power was not about the credibility of the election, but about protecting the country, as he believed there was a conspiracy against him. ${ }^{45} \mathrm{With}$ all the irregularities associated with the 2015 elections and complains from the camps of the major contending parties (APC and PDP) regarding the results in some states, it could not have been said that electoral credibility was a significant trigger of the willingness of the incumbent president to concede defeat and hand over power. ${ }^{46}$ Rather, the desire of President Jonathan to ensure peace in the country and pressures from local and international constituencies were major factors (Idowu and Mimiko 2020).

Although the election was relatively credible, the incumbent president did not believe the results, had lost faith in the INEC and believed there were underage voters in the North (opposition stronghold)..$^{47}$ On his part, a PDP chieftain opined that it was obvious that INEC determined the outcome of the election because whereas card readers were used in the South (incumbent stronghold), they were not used in the North (opposition stronghold), which gave room for indiscriminate and underage voting. ${ }^{48}$ Nonetheless, President Jonathan conceded defeat irrespective of those irregularities. It would, therefore, be misleading to believe that the election management system had a significant effect on the alternation. Furthermore, a respondent asserted:

"I think another factor is that the nature of Jonathan himself... He was not someone who

wanted to desperately hold onto power... If it was Yahya Jammeh for example, or Laurent

Gbagbo..., the story may have been different." ${ }^{49}$

President Jonathan only conceded defeat and handed over power because he had continuously stressed before the commencement of election that "his own personal ambition was not worth the blood of any Nigerian, he therefore, relinquished power to allow peace reign." 50

\footnotetext{
${ }^{44}$ Interview with the Special Adviser on Media and Publicity to President Muhammadu Buhari, Nigeria, 19.12.2018; Interview with the Deputy Director, Election Monitoring Department, INEC, Nigeria, 18.12.2018.

${ }^{45}$ Interview with the Special Adviser on Media and Publicity to President Goodluck Jonathan, Nigeria, 27.12.2018.

${ }^{46}$ Interview with the Deputy Country Director, NDI, Nigeria, 18.12.2018.

${ }^{47}$ Interview with the National Publicity Secretary, APC, Nigeria, 20.12.2018.

${ }^{48}$ Interview with the National Publicity Secretary, PDP, Nigeria, 15.12.2018.

${ }^{49}$ Interview with the National Publicity Secretary, APC, Nigeria, 20.12.2018.

${ }^{50}$ Interview with the Special Adviser on Media and Publicity to President Goodluck Jonathan, Nigeria, 27.12.2018.
} 
Interviewees' submission that the personality of Jonathan and other factors were key to the alternation of power between incumbent and opposition governments in Nigeria have also been stressed in the literature (Adeniyi 2017; Araba and Braimah 2015; The Nigerian Voice 2015; Premium Times 2015).

\section{Discussion}

This study found that, in Ghana, the election management system put in place for the various transition elections was key to the peaceful alternations of power between incumbent and opposition governments so far experienced in the country. The election management system produced free, fair and credible elections which largely made it difficult on all occasions for the incumbent presidents/parties who had lost elections to attempt to hold on to power. In line with established facts in the literature (Heywood 2002; Jinadu 1997, 2), the system determined how the incumbents who had lost elections in the country reacted by conceding defeat and handing over power. Peaceful alternations were largely possible because the election management system was transparent. This is as also established in literature: when the election management system has transparency and credibility, there is increased acceptability of election outcome by both losers and winners (Al Musbeh 2011; Kerevel 2009, 3; Mozaffar and Schedler 2002, 7-10). Although the Ghanaian election management system still faces some challenges, it still maintains very high degree of credibility and transparency to invoke acceptability, and the degree of flaws do not undermine the credibility of the process. The system thus played a significant role in all three alternations. Other factors which contributed to the peaceful alterations include the personality of the defeated presidents and their desire to preserve national interest and security, the role of civil societies, the Inter Party Advisory Committee (IPAC) and the international community, the democratic culture in Ghana and the vigilance of Ghanaians (Idowu 2018; Idowu and Mimiko 2020). All these factors worked together to instill electoral credibility and integrity which in turn, ensured that defeated incumbents had no excuse but to peacefully hand over power to opposition governments.

On the other hand, the election management system put in place for the 2015 presidential elections played a rather insignificant role in the peaceful alternation in Nigeria. Although there were several innovations in the election management system in 2015 to improve electoral credibility and transparency, they did not significantly influence the decision of incumbent President Goodluck Jonathan to peacefully and willingly concede defeat and hand over power to opposition leader Muhammadu Buhari, who won the election. The elections were fraught with varying degrees of irregularities like underage voting, malfunctioning of the smart card readers in some parts of the country, especially in some areas believed to be the strongholds of the incumbent president, 
temporary hacking of INEC's website and violence. We found that these irregularities were strong enough to cast aspersions on the credibility of the process. These findings have also been established in the literature (Adeniyi 2017, xxii, 117; Alade 2015; Kuna as cited in Adeniyi 2017, 178): with all the irregularities associated with the 2015 election with complaints coming from the camps of the major contesting political parties (APC and PDP), it could not be said that the election management system played significant role in the willingness of the incumbent president to concede defeat and hand over power to the opposition. Hence, factors such as the personality of Jonathan, the National Peace Committee (NPC) set up to ensure a peaceful transition and pressure from international and domestic communities were largely responsible for a successful transfer of power from incumbent president to an opposition party in Nigeria (Idowu 2018).

The personality of the then incumbent President Jonathan as a major factor in the 2015 peaceful alternation of power has often been buttressed in the literature and even by the incumbent president himself (Jonathan 2018). Despite the irregularities recorded in the 2015 presidential election, it has been argued that the major reason why there was no total breakdown of the entire process was President Jonathan's commitment to allowing INEC a free hand (Araba and Braimah 2015). The foregoing could also have accounted for by his willingness to concede defeat in spite of series of irregularities linked with the electoral process (Idowu 2018; Jonathan 2018; Mimiko 2017, 402). Furthermore, President Jonathan, who constantly stressed that his ambition was not worth the blood of any Nigerian (Jonathan 2018), thus, displayed a real sense of sportsmanship even when he had reasons (due to observed irregularities) to act otherwise.

President Jonathan himself attributed his action to concede defeat to opposition party not to election management system but to the need to check his ambition as the consequences of not doing so may have been dire not only for Nigeria but for Africa (Premium Times 2015). He was concerned about his personal ambition obstructing the democratic system. In his words,

"Democracy has to be nurtured to grow. Strong democratic institutions are the backbone

and future of our democracy. They must be protected and nurtured. As for me, as a matter of principle, it is always the nation first" (Jonathan in Premium Times 16 April 2015).

Adeniyi (2017, xxi), however, painted a picture of the then incumbent President Goodluck Jonathan being begged to accept the election results and concede defeat. The Attorney General and Justice Minister, Mohammed Adoke, the Aviation Minister, Osita Chidoka, and the Special Assistant to the President on Domestic Affairs, Waripamo-Owei Dudafa, were all kneeling before the President, begging him to concede defeat. They persuaded President Jonathan to call to congratulate his opponent. This account has, nevertheless, received some repudiations (Nwosu 2017; Olawoyin 2017). 


\section{Conclusion and Future Research}

This article has established that because the election management system produced credible elections in Ghana, it was able to influence all three peaceful alternations of power between incumbent and opposition governments. That is, incumbent governments peacefully and willingly conceded defeat because they felt the elections had integrity. In Nigeria, the system is still largely flawed, and so the peaceful alternation of power in the country could not be traced to the role of a credible election management system. In other words, the incumbent president peacefully and willingly conceded defeat in spite of a largely flawed election management system. The personality of the incumbent was therefore identified as one of the main factors influencing the peaceful alternation of power in Nigeria. The general lesson from these findings that needs to be explored in future studies, therefore, is that there might be different pathways that secure peaceful alterations of power, one of them requiring a credible election management system, another the willingness of the incumbent candidates to concede defeat despite a largely flawed election management system. ${ }^{51}$

Our study is limited by its time frame. At the time of research, Nigeria had had only one experience of peaceful alternation of power between incumbent and opposition governments, so the study was conducted as a test case. The 2019 presidential elections in Nigeria saw the incumbent president and party winning. Future election management and transitions in Nigeria and Ghana will present opportunities for further research, to update the trends and examine whether indeed both countries have made advances on the path to democratic consolidation by experiences of credible elections and alternation between incumbent and opposition.

\section{References}

Adebiyi, Oluwashina. 2015. "Kudos or Knocks: Assessing the Performance of INEC in the 2015 General Elections in Nigeria." Presented at The Electoral Institute (TEI) conference, Abuja, July 17-18, 2015.

Ace Project. 2018. "Electoral Management." Accessed September 15, 2018. http://www.aceproject.org/ace-en/topics/em/default.

Adeniyi, Segun. 2017. Against the Run of Play: How an Incumbent President was Defeated in Nigeria. Lagos: Kachifo Limited.

Afrobarometer Data, Ghana, R7. 2016/2018. Accessed December 18, 2019. http://www.afrobarometer.org/online-data-analysis/analyse-online.

\footnotetext{
${ }^{51}$ Sufficient empirical data could serve as a basis of a qualitative comparative analysis of several cases.
} 
Afrobarometer Data, Nigeria, R7. 2016/2018. Accessed March 17, 2019. http://www.afrobarometer.org/online-data-analysis/analysis-online.

Alade, Abiodun. 2015. "INEC Website Hacked." Vanguard, March 28, 2015. http://www.vanguardngr.com/2015/03/inec-website-hacked.

Al Musbeh, Muhammad. 2011. "Managing Elections: Definition and Classification of Election Management Bodies.” https://doi.org/10.2139/ssrn.2271279.

Ameh, Comrade. 2014. "2015: Nigeria Will Break up if Jonathan is not Re-elected-Ezeife." Daily Post, January 15, 2014. http://www.dailypost.ng/2014/01/15/2015-nigeria-will-breakjonathan-re-elected-ezeife/.

Araba, Akeem and Joseph Braimah. 2015. "Comparative Study of 2011 and 2015 Presidential Elections in Nigeria." Global Journal of Human-Social Science 15, no. 7: 48 - 54.

Asante-Kissi, Emmanuel. 2012. "Electoral Commission and Election Management in Ghana (1993-2008)". MPhil Thesis, University of Ghana, Ghana.

Ayee, Joseph. 1997. "Ghana’s 1996 General Elections: A Post-mortem.” Harare: AAPS Occasional Paper Series 1, no. 1: $1-27$.

BBC News. 2016. "Gambia's Jammeh Loses Presidential Elections to Adama Borrow in Shock Election Result." $\quad B B C, \quad$ December 2016. https://googleweblight.com/i?u=https://www.bbc.com/news/world-africa38183906andhl=en-NG.

Bob-Milliar, George. 2014. "Party Youth Activists and Low-intensity Electoral Violence in Ghana: A Qualitative Study of Party Foot Soldiers' Activism." African Studies Quarterly 15, no. 1: 125-152.

Bratton, Michael. 1997. "Civil Society and Political Transition in Africa." Institute for Development $\begin{array}{llllll}\text { Research (IDR) Reports 11, } & \text { no. }\end{array}$ https://africanphilanthropy.issuelab.org/resources/19673/19673.pdf.

Carter Center. 1999. "Post-election Statement on Nigerian Elections, March 1, 1999." Report Issued in Response to the 27 February Presidential Election of 1999. Accessed on September 15, 2018. http://www.cartercenter.org/news/documents/doc891.html.

Catt, Helena, Michael Maley, Alan Wall and Peter Wolf. 2014. Electoral Management Design. Stockholm: International Institute for Democratic Electoral Assistance.

Cho, Wonbin and Carolyn Logan. 2014. "Looking toward the Future: Alternations in Power and Popular Perspectives on Democratic Durability in Africa." Comparative Political Studies 47, no. 1: 30-54. https://doi.org/10.1177/0010414013488534.

Debrah, Emmanuel. 2001. "Mechanisms for Ensuring Free and Fair 2000 General Elections in Ghana." In Deepening Democracy in Ghana: Politics of the 2000 Elections, edited by Ayee Joseph, 75-85. Accra: Freedom Publications.

Gyekye-Jandoh, Maame. 2016. "Civic Election Observation and General Elections in Ghana." In Issues in Ghana's Electoral Politics, edited by Kwame Nkrumah, 35-62. Dakar: Council for the 
Development of Social Science Research in Africa (CODESRIA). https://doi.org/10.2307/j.ctvh8r21x.8.

Gyimah-Boadi, Emmanuel. 1999. "Ghana's Elections: The Challenges Ahead.” In Democratization in Africa, edited by Larry Diamond Larry and Marc Plattner, 170-183. Baltimore/London: The John Hopkins University Press.

Heywood, Andrew. 2002. Politics. New York: Palgrave Macmillan.

Human Rights Watch. 2007. "Nigeria: Presidential Election Marred by Fraud, Violence.” Accessed on September 20, 2018. https://www.hrw.org/news/2007/04/25/nigeria-presidentialelection-marred-fraud-violence.

Huntington, Samuel. 2009. "How Countries Democratize." Political Science Quarterly 124, no. 1: 31 69. https://doi.org/10.1002/j.1538-165X.2009.tb00641.x.

Dunne, Sean and Scott Smith. 2012. Electoral Management during Transition: Challenges and Prospects. Stockholm: International Institute for Democratic Electoral Assistance.

Idowu, Harrison. 2018. "Election management and peaceful democratic transition in Ghana and Nigeria.” M.Sc. thesis, Obafemi Awolowo University, Ile-Ife, Nigeria.

Idowu, Harrison and Oluwafemi Mimiko. (2020, forthcoming). "Enabling Factors for Peaceful Political Power Alternation and Democratic Consolidation in Ghana and Nigeria." Taiwan Journal of Democracy.

Independent Electoral Commission of Gambia. 2016. "The Total of Final Election Results." 5 December, Gambia IEC.

INEC. 2014. "Report of the Technical Committee on Election Project Plan (TCEPP), 2015." INEC, Abuja: Nigeria.

Jinadu, L. Adele. 1997. "Matters Arising: African Elections and the Problem of Electoral Administration." African Journal of Political Science 2, no. 1: 1-11.

Jinadu, Adele. 2014. "Lessons from Electoral Management and Process in West Africa." South African Institute of International Affairs, Governance and APRM Programme, Occasional paper 194. https://www.aprmtoolkit.saiia.org.za/documents/academic-papers/507lessons-from-electoral-process-in-west-africa/file.

Jonathan, Goodluck. 2018. My Transition Hours. Kingwood: Ezekiel Books.

Kerevel, Yann. 2009. Election Management Bodies and Public Confidence in Elections: Lessons from Latin America. Washington D.C.: IFES Fellowships in Democracy Studies.

Kurfi, Amadu. 2005. Nigerian General Elections: My Role and Reminiscences. Ibadan: Spectrum Books.

Little, Andrew, Joshua Tucker and Tom LaGatta. 2015. "Elections, Protest and Alternation of Power." Journal of Politics 77, no. 4: 1142-1156. https://doi.org/10.1086/682569.

Lopez-Pintor, Rafael. 2000. Electoral Management Bodies as Institutions of Governance. New York: UNDP. 
Marc, Alexandre, Neelam Verjee and Stephen Mogaka. 2015. The Challenge of Stability and Security in West Africa. Africa Development Forum series. Washington, DC: World Bank. https://doi.org/10.1596/978-1-4648-0464-9.

Mbaeze, Netchy, Chukwuma Rowland Okoli and Willy Okonkwo. 2017. "Political Power Alternation and Electoral Violence in post-Colonial Africa: Experiences in Nigeria and Kenya, 1999-2016." Social Scientia Journal of the Social Science and Humanities 2, no. 3: 18-32.

Mimiko, Oluwafemi. 2018. "Trump, Tillerson and the Restructuring Agenda." Tribune Online, March 22, 2018. http://www.tribuneonlineng.com/trump-tillerson-and-the-restructuringagenda/.

Mimiko, Oluwafemi. 2017. Democradura: Essays on Nigeria's Limited Democracy. Durham: Carolina Academic Press.

Mozaffar, Shaheen and Andreas Schedler. 2002. "The Comparative Study of Electoral Governance- Introduction." International Political Science Review 23, no. 1: 7-10. https://doi.org/10.1177\%2F0192512102023001001.

Nadean, Richard and Andre Blais. 1993. "Accepting the Election Outcome: Effect of Participation on Losers' Consent." British Journal of Political Science 23, no. 4: 553-563. https://doi.org/10.1017/S0007123400006736.

National Democratic Institute. 2008. Final NDI Report on Nigeria's 2007 Elections. Abuja, Nigeria: National Democratic Institute for International Affairs.

Norris, Pippa. 2014. Why Electoral Integrity Matters. Cambridge: Cambridge University Press. https://doi.org/10.1017/CBO9781107280861.

Nwosu, Iheanacho. 2017. "Adeniyi Faults Jonathan on Alleged Distortion of Book." Sun News Online, May 1, 2017. http://www.sunnewsonline.com/adeniyi-faults-jonathan-on-allegeddistortion-of-book.

Oladesu, Emmanuel. 2014. “Will Nigeria Disintegrate in 2015?” The Nation Online, December 31, 2014. http://www.thenationonline.ng.net/will-nigeria-disintegrate-2015/.

Oliva, Fabio. 2011. “'Learning to Lose': Accepting Electoral Outcomes.” In The Role of Elections in Peace Processes, 19-32. Turin: United Nations System Staff College.

Omotola, Shola. 2010. "Elections and Democratic Transition in Nigeria under the Fourth Republic." African Affairs 109, no. 437: 1-19. https://doi.org/10.1093/afraf/adq040.

Omotola, Shola. 2011. "Unconstitutional Changes of Government in Africa: What Implications for Democratic Consolidation?” Nordic Africa Institute. Discussion Paper 70.

Oyekanmi, Babatunde. 2015. "2015 General Elections and the Role of INEC.” Presented at the Electoral Institute (TEI) Conference, Abuja, July 17-18.

Patton, Michael. and Michael. Cochran. 2002. A Guide to Using Qualitative Research Methodology. Geneva: Medecins Sans Frontieres. 
Premium Times. 2015. "Why I conceded Defeat to Buhari-Jonathan." Premium Times, April 16, 2015. https://www.premiumtimesng.com/news/headlines/181550-why-i-concededdefeat-to-buhari-jonathan.html.

Olawoyin, Oladeinde. 2017. "Jonathan Speaks on Olusegun Adeniyi's Book, says 'Against the Run of Play' Contains Distorted Claims." Premium Times, April 29, 2017. http://www.googleweblight.com/i?u=https://www.premiumtimesng.com/news/headli nes/229973-jonathan-speaks-olusegun-adeniyis-book-says-run-play-contains-distortedclaims.htmlandhl=en-NG.

Sanusi, Ibraheem and Rizzan Nassuna. 2017. Emerging Trends in Africa's Electoral Processes. Johannesburg: South African Institute of International Affairs.

Schedler, Andreas. 1998. "What is Democratic Consolidation?" Journal of Democracy 9, no. 2: 91107. https://doi.org/10.1353/jod.1998.0030.

Songwe, Vorrath. 2015. "African Leadership Transitions Tracker." March 25, 2015. http://www.brookings.edu/interactives/african-leadership-transitions-tracker/. Last modified December 18, 2019.

Songwe, Vorrath. 2016. "Africa's Mixed Political Transitions in the 3 Gs: Gabon, the Gambia and Ghana.” December 22, 2016. http://www.brookings.edu/blog/africa-infocus/2016/12/22/africas-3-gs-gabon-the-gambia-and-ghana.

Souaré, Issaka. 2010. Critical Assessment of Security Challenges in West Africa. Pretoria, South Africa: Institute for Security Studies Situation Report.

Stewart, John. 2006. "A Banana Republic? The Investigation into Electoral Fraud by the Birmingham Election Court." Parliamentary Affairs 59, no. 4: 654-667. https://doi.org/10.1093/pa/gsl020.

The Guardian. 2016. "Gambian President Yahya Jammeh Rejects Election Results.” The Guardian, December $10, \quad 2016$. https://googleweblight.com/i?u=https://www.theguardian.com/world/2016/dec/10/g ambian-president-rejects-election-results-yahya-jammeh-adama-barrowandhl=en-NG.

The Nation. 2015. “Tompolo: I Insist Nigeria Will Break if Jonathan Loses.” The Nation, January 30, 2015. https://thenationonlineng.net/tompolo-insist-nigeria-ll-break-jonathan-loses/.

The Nigerian Voice. 2015. "Violence, Electoral Malpractices Mar elections in Imo." The Nigerian Voice, April 20, 2015. http://www.thenigerianvoice.com/print/175739/1/violenceelectoral-malpractices-mar-elections-in-imo.html.

Thornycroft, Peta, Chris Graham and Louis Emmanuel. 2017. "Zimbabwe Crisis: 'Moment of Hope' as Robert Mugabe's Iron Grip on Power Evaporates." The Telegraph, November 15, 2017. http://www.telegraph.co.uk/news/2017/11/14/tanks-seen-heading-towardszimbabwe-capital-harare/.

Transition Monitoring Group. 2014. "Do the Votes Count? Final Report of the 2003 General Elections by the Transition Monitoring Group.” Abuja: TMG.

Whitehead, Laurence. 2003. Democratization: Theory and Experience. Oxford: Oxford University Press. 


\section{Appendix \\ 1. Operationalizing the Dependent and Independent Variables Independent Variable}

Election management system is operationally defined as the plans/processes or system put in place to ensure that election management is conducted seamlessly. It produces transparent and credible elections when it gives room for free and fair elections and credible voters' register, does not ensure incumbent recycling, does not provoke electoral/democratic frustration through violence, discourages voter inducement and ensures that the electoral process is free from intimidation, repression and fraud.

\section{Dependent Variable}

Peaceful alternation of power is operationally defined as a situation wherein an incumbent leader or party loses an election, concedes defeat and willingly hands over power to an opposition party/candidate who had won the election. It occurs when there is a seamless transfer of political power from an incumbent government to an opposition government. This is similar to Little Tucker and Lagatta's (2015) 'democratic' power alternation.

\section{Question Guide for Ghanaian Respondents}

1. Does election management have any effect/impact on peaceful alternation of power?

2. How are elections managed in Ghana? What is the entire process involved in the elections (pre-election period, the election proper and the post-election period)? How do political parties, candidates, the electorate and the EC conduct themselves during these periods?

3. Would you say that the alternations of power between incumbent and opposition parties/presidents so far experienced in Ghana were peaceful?

4. Would you say the way the elections were conducted had any influence on the alternation of power between incumbent and opposition in Ghana? For example, can you say that the manner in which the 2016 presidential election was conducted had any impact on the willingness of the President John Dramani of the NDC to concede defeat and hand over power to the opposition, and how? In other words, do you think his concession and handing over of power was a result of his conviction that the election was free, fair and credible?

5. What do you think would have made these presidents to behave otherwise (to refuse to concede defeat and hold on to power)?

\section{Question Guide for Nigerian Respondents}

6. Does election management systems have any effect/impact on peaceful alternation of power?

7. How are elections managed in Nigeria? What is the entire process involved in the elections (pre-election period, the election proper and the post-election period)? How do political parties, candidates, the electorate and INEC conduct themselves during these periods?

8. Would you say that the alternation of power between incumbent and opposition parties/presidents so far experienced in Nigeria was peaceful?

9. Would you say the way the elections were conducted had any influence on the alternation of power between incumbent and opposition in Nigeria? For example, can you say that the manner in which the 2015 presidential election was conducted had any impact on the 
willingness of the Goodluck Jonathan of the PDP to concede defeat and hand over power to the opposition, and how? In other words, do you think his concession and handing over of power was a result of his conviction that the election was free, fair and credible?

10. What do you think would have made him (President Jonathan) to behave otherwise (to refuse to concede defeat and hold on to power)?

\section{Information on Political Parties and Election Results leading to Alternation of Power in}

\section{Ghana}

Table 1. Results of the 2000 Ghanaian Presidential Election

\begin{tabular}{|l|l|l|l|l|l|}
\hline Party & Name of candidate & $\begin{array}{l}\text { Votes received at } \\
1^{\text {tt }} \text { round }\end{array}$ & $\begin{array}{l}\text { \% of votes } \\
\text { received at } 1^{\text {st }} \\
\text { round }\end{array}$ & $\begin{array}{l}\text { Votes received at } \\
2^{\text {nd }} \text { round }\end{array}$ & $\begin{array}{l}\text { \% of votes } \\
\text { received at } 2^{\text {nd }} \\
\text { round }\end{array}$ \\
\hline NPP & $\begin{array}{l}\text { John Agyekum } \\
\text { Kufuor }\end{array}$ & $3,131,739$ & $48.17 \%$ & $3,631,263$ & $56.90 \%$ \\
\hline NDC & $\begin{array}{l}\text { John Evans Atta } \\
\text { Mills }\end{array}$ & $2,895,575$ & $44.54 \%$ & $2,750,124$ & $43.10 \%$ \\
\hline PNC & Edward Mahama & 189,659 & $2.92 \%$ & - & - \\
\hline CPP & George Hagan & 115,641 & $1.78 \%$ & - & - \\
\hline NRP & Augustus Obuadum & 78,629 & $1.21 \%$ & - & - \\
\hline GCPP & $\begin{array}{l}\text { Daniel Augustus } \\
\text { Lartey }\end{array}$ & 67,504 & $1.04 \%$ & - & - \\
\hline UGM & $\begin{array}{l}\text { Charles Wereko- } \\
\text { Brobby }\end{array}$ & 22,123 & $0.34 \%$ & - & - \\
\hline & & $\begin{array}{l}\text { Total valid votes }= \\
6,500,870\end{array}$ & & $\begin{array}{l}\text { Total valid votes }= \\
6,381,387\end{array}$ & \\
\hline
\end{tabular}

Source: Authors' Compilation from 2000 Presidential Election in Ghana (African Elections Database).

Table 2. Results of the 2008 Ghanaian Presidential Election

\begin{tabular}{|l|l|l|l|l|l|}
\hline Party & Name of candidate & $\begin{array}{l}\text { Votes received at } \\
1^{\text {st }} \text { round }\end{array}$ & $\begin{array}{l}\text { \% of votes } \\
\text { received at } \\
\text { round }\end{array}$ & $\begin{array}{l}\text { Votes received at } \\
2^{\text {nd }} \text { round }\end{array}$ & $\begin{array}{l}\text { \% of votes } \\
\text { received at } 2^{\text {nd }} \\
\text { round }\end{array}$ \\
\hline NDC & $\begin{array}{l}\text { John Evans Atta } \\
\text { Mills }\end{array}$ & $4,056,634$ & $47.92 \%$ & $4,521,032$ & $50.23 \%$ \\
\hline NPP & Nana Akufo-Addo & $4,159,439$ & $49.13 \%$ & $4,480,446$ & $49.77 \%$ \\
\hline CPP & Paa Kwesi Nduom & 113,494 & $1.34 \%$ & - & - \\
\hline PNC & Edward Mahama & 73,494 & $0.87 \%$ & - & - \\
\hline DFP & $\begin{array}{l}\text { Emmanuel Ansah- } \\
\text { Antwi }\end{array}$ & 27,889 & $0.33 \%$ & - & - \\
\hline & $\begin{array}{l}\text { Kwasi Amoafo- } \\
\text { Yeboah }\end{array}$ & 19,342 & $0.23 \%$ & - & - \\
\hline DPP & Thomas Ward-Brew & 8,653 & $0.10 \%$ & - & - \\
\hline RPD & Kwabena Adjei & 6,889 & $0.08 \%$ & - & - \\
\hline & & $\begin{array}{l}\text { Total valid votes }= \\
8,465,834\end{array}$ & & $\begin{array}{l}\text { Total valid votes }= \\
9,001,478\end{array}$ & \\
\hline
\end{tabular}

Source: Authors' Compilation from 2008 Presidential Election in Ghana (African Elections Database).

Table 3. Results of the 2016 Ghanaian Presidential Election

\begin{tabular}{|l|l|l|l|}
\hline Party & Name of candidate & Votes received & $\%$ of votes received \\
\hline
\end{tabular}




\begin{tabular}{|l|l|l|l|}
\hline NPP & Nana Akufo-Addo & $5,755,758$ & $53.72 \%$ \\
\hline NDC & John Dramani Mahama & $4,771,188$ & $44.53 \%$ \\
\hline PPP & Paa Kwesi Nduom & 106,092 & $0.99 \%$ \\
\hline CPP & $\begin{array}{l}\text { Ivor Kobina } \\
\text { Greenstreet }\end{array}$ & 25,552 & $0.24 \%$ \\
\hline PNC & Edward Mahama & 22,298 & $0.21 \%$ \\
\hline NDP & $\begin{array}{l}\text { Nana Konadu } \\
\text { Agyeman-Rawlings }\end{array}$ & 16,935 & $0.16 \%$ \\
\hline & Jacob Osei Yeboah & 15,911 & $0.15 \%$ \\
\hline & $\begin{array}{l}\text { Total valid votes }= \\
10,713,734\end{array}$ & \\
\hline
\end{tabular}

Source: Authors' Compilation from 2016 Presidential Election in Ghana (Ghana web, 2017; Ghana EC).

5. Information on Political Parties and Election Results leading to Alternation of Power in Nigeria

Table 4. Results of the 2015 Nigerian Presidential Election

\begin{tabular}{|l|l|l|l|}
\hline Party & Name of Candidate & Votes received & \% of vote received \\
\hline APC & $\begin{array}{l}\text { Maj. Gen. Muhammadu } \\
\text { Buhari (rtd) }\end{array}$ & $15,424,921$ & $53.96 \%$ \\
\hline PDP & $\begin{array}{l}\text { Dr. Goodluck Ebele } \\
\text { Jonathan }\end{array}$ & $12,853,162$ & $44.96 \%$ \\
\hline APA & Ayeni Musa Adebayo & 53,537 & $0.19 \%$ \\
\hline ACPN & Alh. Ganiyu o. Galadima & 40,311 & $0.14 \%$ \\
\hline CPP & Chief Sam Eke & 36,300 & $0.13 \%$ \\
\hline AD & Rafiu Salau & 30,673 & $0.11 \%$ \\
\hline ADC & Dr. Mani Ibrahim Ahmad & 29,666 & $0.10 \%$ \\
\hline PPN & $\begin{array}{l}\text { Allagoa Kelvin Chinedu } \\
\text { NCP }\end{array}$ & 24,475 & $0.09 \%$ \\
\hline AA & $\begin{array}{l}\text { Jci sen. Tunde } \\
\text { Anifowose-kelani }\end{array}$ & 24,455 & $0.09 \%$ \\
\hline UPP & $\begin{array}{l}\text { Chief (Dr.) Chekwas } \\
\text { Okorie }\end{array}$ & 18,220 & $0.08 \%$ \\
\hline KOWA & Comfort Oluremi Sonaiya & 13,076 & $0.06 \%$ \\
\hline UDP & $\begin{array}{l}\text { Godson Mgbodile } \\
\text { Ohaenyem Okoye }\end{array}$ & 9,208 & $0.05 \%$ \\
\hline HOPE & $\begin{array}{l}\text { High chief } \\
\text { Ambrose }\end{array}$ & 7,435 & $0.03 \%$ \\
\hline Source & $28,587,564$ & $0.03 \%$ \\
\hline
\end{tabular}

Source: Authors' Compilation from 2015 Presidential Election in Nigeria (Africa Elections Database; INEC) 